\title{
Occupational Health and Safety Animated Learning Videos: Validity and Feasibility
}

\author{
Riyan Arthur ${ }^{1 *}$, Anisah ${ }^{2}$, Ima Wfiayanti ${ }^{3}$, Jaelani Sidlk ${ }^{4}$ \\ 1,2,3 Building Construction Vocational Education, State University of Jakarta, Indonesia \\ ${ }^{4}$ Mechanical Engineering, Wahidiyah Kediri University, Kediri, Indonesia \\ e-mail: arthur@unj.ac.id¹, anisah@unj.ac.id², wijayantu123@gmail.com³
}

\begin{abstract}
This study aims to produce animation learning media on OHS courses with the help of software. This research uses Lee \& Owens development research model. This research is done through 5 stages, namely assessment or analysis, design, development, implementation, evaluation. This research uses questionnaires to test the feasibility of learning media products through the validation of material experts and media experts. Assessments from students using scale instruments designed for validation of experts, materials, students, and construction skilled workers. Learning media products in the form of five animated videos. The rating by media experts of $87.13 \%$ is considered highly feasible. The assessment by the material expert scored at 81.43 which is categorized as very feasible. Assessments by students through limited trials scored $85,86 \%$ of which were categorized as highly feasible. Assessments by construction skilled workers through limited trials get a value of $87 \%$ which is also categorized as highly feasible.
\end{abstract}

Keywords: Animated Videos, Occupational Health, Safety

\section{Introduction}

Understanding of OHS (Occupational Health and Safety) is fundamental for vocational education graduate particularly in the construction industry because it has big risk factors related with the various heavy equipment, poisonous material, dangerous and risky works. Therefore, every construction labor candidate must have knowledge, attitude, and ability to perform OHS procedure. Undergraduate Study Program (S1) Building Engineering Education (PTB) Faculty of Engineering Jakarta State University (FT UNJ) is one of the schools that provide a professional educated labor on construction industry, but unfortunately based on academic data for the last four years mention that there is an unsatisfactory score achievement in OHS course. Less than $25 \%$ students were achieving the highest score, its means that the average ability of college students on OHS courses still in a low level.

Student ability is determined among others by quality of intake student and quality of learning process such as planning, use of teaching materials and media, and lecturer ability to manage the class. Besides, un-optimal education management and lack of education infrastructure such as the availability of loT, internet services, and various software and application could be the cause of variation of student ability. Refers to industry revolution 4.0, information technology-based education such as blended learning, distance learning and hybrid learning become a must (M. Wang, 2018). Following Law No. 2 year 2012 about Higher Education and Regulations of the Ministry of Education and Culture No. 109 year 2013 about Distance Learning, almost all university in Indonesia develop various content of distance learning and blended learning. This education content is allowed students to mobile access the courses material and the courses itself is no longer restricted by space and time (Arthur \& Dwi, 2019; Hamid, Aribowo, \& Desmira, 2017). This condition facilitates the formation of the new trends in industry revolution 4.0 education sector, where the academics context and various technical skills are strengthened by information-technology (Baena, Guarin, Mora, Sauza, \& Retat, 2017). Discuss about academic and learning context involving informationtechnology, the results of the needs analysis on Mechanics Material course in Undergraduate

\footnotetext{
${ }^{*}$ Corresponding author.

Received 03 June 2020; Accepted 16 September 2020; Available online 25 March 2021

(C) 2020 JPI. All Rights Reserved
}

Jurnal Pendidikan Indonesia (JPI) | 1 
Study Program (S1) Building Engineering Education (PTB) Faculty of Engineering Jakarta State University (FT UNJ) also confirm about those opinion (Arthur, Luthfiana, \& Musalamah, 2019). Same research also have been done in OHS course in the same study program which the result can be seen as follow.

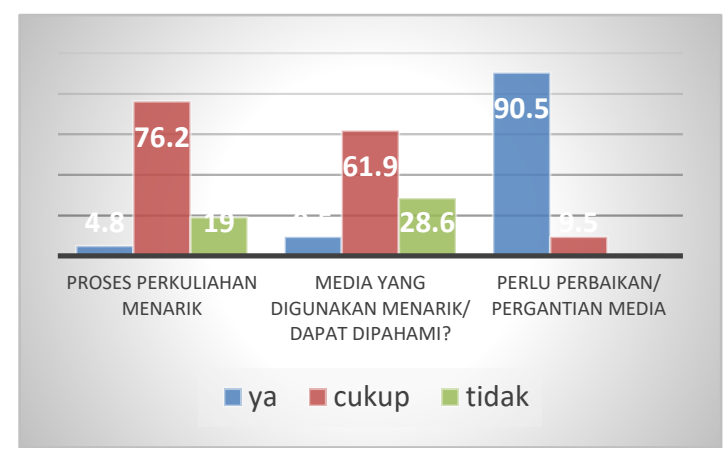

(a)

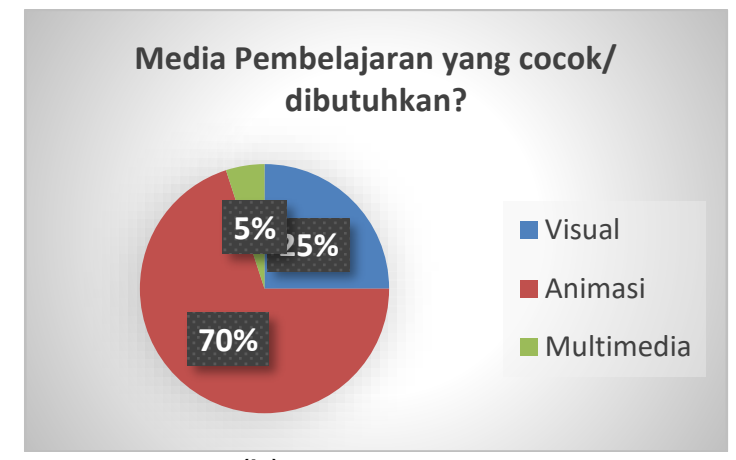

(b)

Figure 1. Results of Analysis of the Needs of OHS Subject Learning Media (\%)

Based on the results of the needs analysis, students need an improvement or replacement of teaching materials. It is interesting that students choose to animation teaching materials rather than visual or multimedia teaching materials. The characteristics of OHS course is more human subject and describe human activities such as risk prevention when student working on laboratory, workshop, or in the field (Ratnasari, 2016: 85), therefore animation video will provide more clear example rather than visual or multimedia. Lecturer or student facilitator demanded for describing OHS procedure in more clear and detail aspects using teaching materials, with the intention to improve student competencies.

Learning media is a tool or intermediary that is useful for facilitating the teaching and learning process in streamlining communication between students and educators (Efanudin \& Setya, 2017: 202). Learning media is a messenger technology, an intermediary tool (Arsyad, 2014) that can be used for learning purposes (Sukir, Soenarto, \& Soeharto, 2017). The use of learning media must be varied, attracting attention, fun (Primasari \& Herlanti, 2014: 68). Selection of good learning media in learning must be creative, communicative, and innovative (Asmara, 2015; Prastiyo, Djohar, \& Purnawan, 2018) so that the learning material becomes simpler (Maulana, Adi, \& Hariyanto, 2019), increase the linkage of students in the learning process (Arthur, Sekartaji, Maulana, \& Dewi, 2019), maximizes all the senses, (Arham \& Dwiningsih, 2016) and can guide students to be more independent in increasing insight, so that they can provide the same information to all students which leads to increased learning outcomes (Miftah, 2015; Muhson, 2010).

Video is a technology for capturing, recording, processing, transmitting and rearranging moving images that convey messages that are factual or fictitious, informative, educational or instructional (Purwanti, 2015: 44). Video as digital media that shows the arrangement or sequence of pictures that give illusions, images and fantasies on moving pictures (Munir, 2014: 348), plus sound that can provide a real picture, and able to manipulate time and place (Rayandra, 2012; Smaldino, Lowther, \& Russell, 2012).

The advantages of video include that it can be used for a long period of time and at any time if the material is still relevant; fun learning media; able to help students in understanding learning material and assisting teachers in the learning process; can be used by the wider community and easily accessible; describe a real and clear state of a process (procedure) and phenomenon (incident); can be easily collaborated with other media such as audio, text and infographics (images) so that it is more effective and fast in conveying messages (material); Suitable for teaching material in the cognitive, behavioral and psychomotor domains (Efanudin Febri \& Wibawa Chendra, 2017; Furi \& Mustaji, 2017; Johari, 2014; Susanti, Harta, Karyana, \& Halimah, 2018). Thus, we need a video that is complete, easy to update and flexible like an animation video. 
Making and developing instructional videos takes a long time; Videos can only be used with the help of computers or gadgets, monitors, projectors (screens) and speakers when used in the learning process; In making video requires a large amount of money; The video is not detailed in the explanation of the material because students must be able to remember each part (Scene), learning with video is considered easier than text so that students are less likely to be more active in interacting with the material (Munir, 2014; Purwanti, 2015; Susanti et al., 2018; Wardoyo Tunggul Cipto, 2015). Therefore, in making this video, it must have adequate equipment, involve a team of experts and be accompanied by uploads on the internet on various digital platforms (such as Youtube and Moodle). Animated video learning media is a combination of text, audio and visual media assisted by various software (Buchari, Sentinowo, \& Lantang, 2015: 1) in an effort to describe a message and teaching material well and clearly (Utami, 2011). The use of animated videos in learning is needed to be able to stimulate students when learning, both in abstract and concrete material so that the delivery is more interesting (W. Lee \& L. Owens, 2004) so that it can be understood by students.

The use of animated videos is proven to improve the learning outcomes of engineering students in engineering courses (Lutfiyanta, 2015; Wardoyo Tunggul Cipto, 2015) as well as subjects in SMK (Efanudin Febri \& Wibawa Chendra, 2017; Rahman, 2014). Animated video media has considerable potential if it is used in learning, namely: providing direct experience to students; Explain abstract lessons; Can be used repeatedly; Can present objects well (Dick, Carey, \& Carey, 2015). Animated videos are very influential in learning because they are proven to attract attention, increase retention (Smaldino et al., 2012) and enables the visualization of imagined concepts, objects, and relationships (Grzyl, Miszewska-Urbańska, \& Apollo, 2017; Law, Geng, \& Li, 2019; Schneider, Beege, Nebel, \& Rey, 2018). Referring to the various problems faced and the description of the animation video learning media above, it can be concluded that it is important to develop a prototype of animation learning media on OHS course in Undergraduate Study Program (S1) Building Engineering Education (PTB) Faculty of Engineering Jakarta State University (FT UNJ).

\section{Method}

This research is a development research by adapting Lee and Owen's model which consists of: assessment or analysis, design, development, implementation and product evaluation (William \& Diana, 2004). This model was chosen because the final result was animation video learning media. Due to various limitations, this research only reached the assessment stage of product development or prototypes (third stage). That is, it does not reach the implementation or evaluation stage. The research was conducted at the Faculty of Engineering, State University of Jakarta (FT UNJ) and the Centro City Apartment Project, West Jakarta. The research was conducted from November 2018 to August 2019. The products were validated by material experts, media experts, students and skilled workers in the building construction field. The media and material validators involved were 3 people, 21 students and 12 skilled workers. Media validator criteria; has the ability in the field of instructional media with a qualification of Master of Education and has experience in the field of educational technology. While the criteria for material experts; have the ability in the field of OHS material, minimum academic level of undergraduate or equivalent KKNI level $\mathrm{VI}$ and have experience in the field of OHS. Student criteria; have taken OHS courses. Criteria for skilled personnel; workers installing iron, stone or concrete related to OHS materials. The instrument used in this research refers to the standard instruments that have been published by the Education Technology Study Program, Faculty of Education, UNJ. With the following assessment criteria:

Table 1. Product Assessment Criteria

\begin{tabular}{lll}
\hline Average Score & Category & Equivalent \\
\hline $80 \%-100 \%$ & Sangat valid & Very Decent \\
$66 \%-79 \%$ & Valid & Worth \\
$56 \%-65 \%$ & Valid Enough & Decent Enough \\
$40 \%-55 \%$ & Less Valid & Not Worth It
\end{tabular}




\begin{tabular}{lll}
\hline Average Score & Category & Equivalent \\
\hline$<40 \%$ & Tidak Valid & Not Worth It \\
\hline & & Source: (Grand, 2013)
\end{tabular}

\section{Result and Discussion Results}

The media experts who became validators of this animated video learning media were two lecturers of Educational Technology, Faculty of Education, UNJ. These validators have expertise in the field of learning media. The two media experts provide an assessment of the feasibility of the animated video learning media which consists of several aspects of the assessment as shown in Table 2.

Table 2. Media Expert Validation Data

\begin{tabular}{cccc}
\hline Indicator & \%V1 & \%V2 & Total \\
\hline Text & $80 \%$ & $75,60 \%$ & $77,80 \%$ \\
Color combinations & $90 \%$ & $90 \%$ & $90 \%$ \\
Animation & $84,56 \%$ & $80 \%$ & $82,28 \%$ \\
Feed format & $90 \%$ & $90 \%$ & $90 \%$ \\
Media use & $100 \%$ & $100 \%$ & $100 \%$ \\
Media implementation & $82,72 \%$ & $82,72 \%$ & $82,72 \%$ \\
\hline
\end{tabular}

Based on the table above, the writing indicators show the results of the validation of media experts with a total percentage of $77.80 \%$. This shows that the writing indicators in the animated video learning media are feasible to use because the text size is appropriate and clear, the font colors are attractive and can be seen. The color combination indicator shows the results of the media expert validation with a total percentage of $90 \%$. This shows that the color combination indicator in the animation video learning media is very feasible to use because the components of the writing and animation color have been made coherently and well, the appearance of the animated video learning media is interesting to see.

The animation indicator shows the results of the media expert validation with a total percentage of $82.28 \%$. This shows that the animation indicator in the animation video learning media is very feasible to use because the animation used is in accordance with the RPS and the animation colors are displayed well and reduces boredom. The presentation format indicator shows the results of the media expert validation with a total percentage of $90 \%$. This shows that the presentation format indicator in the animated video learning media is very feasible to use because the narration presented is in accordance with the material and the animation used can stimulate students to think. The presentation format indicator shows the results of the media expert validation with a total percentage of $100 \%$. This shows that the indicators of media use in animated video learning media are very feasible to use because animated videos are easy to use in an easy way to stop and play back, animated video learning media can help the learning process. The media implementation indicator shows the results of the media expert validation with a total percentage of $82.72 \%$. This shows that the indicators of media use in animated video learning media are very feasible to use because animation video learning media are easy to use because of the instructions for use and have been packaged properly.

Based on the above, it shows that some of the indicators are in the Eligible category and some are in the Very Appropriate category. The suggestions and input from media experts provided are as follows: 1) Improve the typeface with century gothic; 2) Add tools such as speakers to the learning process; 3) Add instructions for the use of animated video learning media, and 4) Pack the animation video learning media properly, for example with a DVD. In general, media experts provide the above suggestions in order to improve learning media so that it can be used optimally. After considering some of the indicators above, the material expert concluded that the animated video learning media for OHS courses were feasible to 
use with minor revisions. Material expert validation was carried out by the Project Manager Health Safety Environment (HSE) for the Centro City Apartment project, the Urban Heights Residences project and PTB UNJ lecturers. These validators have expertise in the field of learning material. The three material experts provide an assessment of the feasibility of the learning material in the animated video which consists of several aspects of the assessment as follows:

Table 3. Material expert validation data

\begin{tabular}{ccccc}
\hline Indicator & $\% \mathbf{V 1}$ & $\% \mathbf{V 2}$ & $\% \mathbf{V 3}$ & Total Percentage \\
\hline Learning objectives & $80 \%$ & $80 \%$ & $68,56 \%$ & $76,18 \%$ \\
Material delivery & $86,76 \%$ & $86,76 \%$ & $70,46 \%$ & $81,32 \%$ \\
Material selection & $95 \%$ & $95 \%$ & $73 \%$ & $86 \%$ \\
\hline \multicolumn{5}{c}{ Total percentage } \\
\hline
\end{tabular}

Based on the results of the material expert validation in the table above, the learning objective indicator shows the result of the material expert validation is $76.18 \%$. This shows that the learning objective indicators in the animated video learning media are feasible to use because the learning objectives and learning indicators have been conveyed in the animated video learning media and the material delivered is in accordance with the learning objectives in the RPS. The material delivery indicator shows the result of the material expert validation is $81.32 \%$. This shows that this indicator is very feasible to use because the material presented has been arranged coherently, the pictures and illustrations have been arranged attractively, the duration of media use has been effective and the material presented is in accordance with the facts and data.

The material selection indicator is a discussion of the material presented in learning media that is adjusted to the level of student development and is related to everyday life. This indicator shows the results of the material expert validation, namely $86 \%$. This shows that this indicator is very suitable for use because the material presented in the animated video is in accordance with the RPS and the level of student development.

Based on the above, it shows that some of the indicators are in the Eligible category and some are in the Very Appropriate category. The suggestions and input from the material experts provided are as follows: Fix errors in writing, add material about potential hazards and their control in every job and add potential hazards of OHS electricity. In general, material experts provide the above suggestions in order to improve learning media so that it can be used optimally. After considering some of the indicators above, the material expert concluded that the animated video learning media for OHS courses were feasible to use with minor revisions.

The results of validation carried out by media experts and material experts in the form of assessments, criticisms and suggestions of the animated video learning media for OHS courses in the form of; 1 . Animated video learning media, which were not packaged after being revised by the validator, must be packaged in DVDs and equipped with a DVD holder to facilitate distribution and use by lecturers who teach OHS courses; 2 . Animated media does not have instructions for use, but after being revised by the media validator, instructions for the use of animated video learning media must be made. This aims to make it easier for lecturers who teach courses to use them; 3 . The written font was replaced, which was originally Times New Romance, after being revised by the media validator, then it was changed to a century ghotic font, which aims to clarify text writing on animated video media.

As for the material revision of the product, namely in the form of: The writing of the previous word there was still an error after being revised, so the writing of the word error had to be corrected, it aimed to clarify the material in the learning video; Previously, the potential hazards did not cover all material after the revision potential hazards have been added in each of these materials to clarify the learning material; Previous risk control did not cover all material, but after revision, each of these materials was added to improve understanding in each 
material; The previous example of OHS electrical hazard protection did not yet exist but after being revised it was added that aims to clarify the material of OHS electricity.

Assessment and student responses to this animated video learning media were carried out by testing the students' products. This product trial was conducted on 21 students who took odd semester OHS courses. This product trial was carried out during OHS lectures which discussed electrical OHS material. The results are as follows:

Table 4. Student Assessment results on Animated Video Media

\begin{tabular}{lllcc}
\hline \multicolumn{1}{c}{ Rated indicators } & $\begin{array}{l}\text { Score } \\
\text { Obtained }\end{array}$ & $\begin{array}{l}\text { Maximum } \\
\text { Score }\end{array}$ & $\begin{array}{l}\text { Total } \\
\text { percentage }\end{array}$ & Category \\
\hline Material Indicators & 180 & 210 & $86 \%$ & Very decent \\
Text Indicator (Text) & 194 & 210 & $92 \%$ & Very decent \\
Design Indicators & 186 & 210 & $88 \%$ & Very decent \\
Animation Indicator & 264 & 315 & $84 \%$ & Very decent \\
Feed Format Indicator & 165 & 210 & $78 \%$ & Worth \\
Media Usage Indicator & 188 & 210 & $89 \%$ & Very decent \\
Media Implementation Indicators & 178 & 210 & $84 \%$ & Very decent \\
\hline \multicolumn{5}{c}{ Total percentage } \\
\hline
\end{tabular}

Student responses provide the suggestions above in order to improve learning media so that it can be used optimally. After considering several indicators, students chose that the animated video learning media for OHS courses were feasible to use with minor revisions. Furthermore, the assessment and responses of skilled workers, namely 12 iron tide workers and stone installation workers in the Westpoint Centro City Apartment project to the material on the animated video learning media product were carried out by testing the product to workers. This product trial was conducted to simplify the process of introducing construction work. At the time of testing the animated video media product discussed the OHS material of construction work. as for the results as follows:

Table 5. Skilled Workers Assessment of Animated Video Media

\begin{tabular}{lcccc}
\hline \multicolumn{1}{c}{ Rated indicators } & $\begin{array}{c}\text { Scores } \\
\text { Earned }\end{array}$ & $\begin{array}{c}\text { Maximum } \\
\text { Score }\end{array}$ & $\begin{array}{c}\text { Total } \\
\text { Percentage }\end{array}$ & Category \\
\hline Writing Indicators & 148 & 180 & 82 & \\
Design Indicators & 212 & 240 & 88 & \\
Material Indicators & 142 & 180 & 79 & \\
\hline & & Total percentage & $\mathbf{8 3 \%}$ & Very Decent \\
\hline
\end{tabular}

The response of skilled workers provides the above suggestions in order to improve learning media so that it can be used optimally with a percentage of $87 \%$. After considering several indicators of skilled workers, it was decided that the animated video learning media for OHS courses were feasible to use with minor revisions. The results of the various inputs and the feasibility process above can be summarized in the image below. the following results have been published via the Youtube channel (http://bit.ly/2NXe79i)

In the validation stage of learning media carried out by media experts and material experts in accordance with their fields. The validation stage of the media expert obtained a total percentage of the value obtained of $87.33 \%$ which means that the animated video learning media is very feasible to use as a learning media for OHS subjects because the use of learning media using animated videos is more meaningful and interesting, easier to accept and understand, it is the same with that expressed by (Lee \& Owens, 2004: 127). The material expert validation stage obtained a total percentage of the value obtained of $82.21 \%$ which was categorized as Very feasible with the material contained in the animated video learning media for OHS courses. These results support the opinion of Hokanson, Cliton and Kaminski (2018) 
which states that animated videos are able to present material that is difficult to explain in a concrete way and can present learning material in detail.

After the validation stage by the learning media product experts, it was also carried out by testing the product of OHS animation video learning media with electrical OHS material to students who got an assessment percentage of $85.86 \%$ which means it is very feasible to be used as a variation of learning media. Product trials were also carried out on skilled workers with OHS material construction work who got a total percentage value of $83 \%$, which means that it is very feasible to be used as one of the OHS learning media. The results of this research on animated video learning media are in line with the research conducted by Wardoyo (2015) the feasibility of the resulting animated video learning media product was able to increase student interest in learning by $(20.70 \%)$ after using the media. These results are in line with research conducted by Pallett et al (2018) which states that learning media products that have good quality can improve feedback or learning outcomes from students.

\section{Discussion}

OHS material is an important issue because it involves the mentality of workers and the sustainability of a construction job. Various efforts have been made so that OHS gets special attention in various fields, both directly (Senouci, Al-Abbadi, \& Eldin, 2015), integration in BIM (Ganah \& John, 2015) as well as by using various OHS instruments and models (Arthur, Rouf, Rahmayanti, \& Maulana, 2019; Endroyo, Yuwono, Mardapi, \& Soenarto, 2015; Zahoor, Chan, Utama, \& Gao, 2015). But more than that, OHS should have been studied since school and college through learning (Grytnes, Grill, Pousette, Törner, \& Nielsen, 2017; Q. Wang \& Zhang, 2018). The subject matter of OHS at the PTB FT UNJ S1 includes, OHS basics, OHS construction work, OHS lift and transport and OHS fire management. As for this learning media, it provides several advantages and disadvantages. The advantages of this animated video learning media product are: this animated video learning media increases students' enthusiasm for learning, is able to provide a sense of pleasure when the teaching and learning process takes place, increases understanding in the learning process. The shortcomings of this animated video learning media product, namely: In its use, lecturers need to bring speakers, learning media requires the help of a laptop or projector (Dick et al., 2015; Koper \& Tattersall, 2010; Msonde \& Van Aalst, 2017; W. Lee \& L. Owens, 2004). Therefore, to minimize the shortcomings of this animation learning media, the media is uploaded to the You Tube channel (http://bit.ly/38D0ofy) and Moodle (http://ptbunj.com/).

This research is an internal evaluation effort for lectures as well as updating learning tools, especially media. The results showed that the media has an important role for learning in higher education, especially in the field of OHS construction. That the product of OHS learning media is suitable for use is an indication of how students in this millennial era need a full package in a concrete, attractive, realistic and valuable sense. This condition can be seen in the enthusiasm and positive results obtained from students when testing the OHS animation learning media (Prastiyo et al., 2018). This OHS animation learning media was also tested on construction workers in the field. Initially this activity was not included in the previous research planning. However, at the request of a validator who worked on one of the projects, this media was tested directly in a construction project by means of direct learning in an open classroom. Departing from these conditions, it was found that not all construction workers in the field (skilled workers) had knowledge or skills in construction OHS. This means that it should be a concern for the parties concerned. Experiments in construction projects obtained results that were more or less the same as those in the OHS class which consisted of students. The difference is that in construction there are more questions that are applied than theoretical. The response of construction workers to OHS learning media is also very positive in the sense that it is very feasible.

Among the media indicators that were validated and revised, the text (text) indicator of the selection and font size was the lowest. These results basically indicate that the function of the media as a messenger must be clear and real. A biased understanding of the lack of conveyance of messages makes the media less effective later (Schneider et al., 2018). Animation is a special feature and focal point of this OHS learning media. therefore, the use of 
animations such as emerging characters as well as the movement of these characters becomes the focus for validators as well as students (Liao, Chen, \& Shih, 2019), It will take a while for the fix to work as it should. Although in the assessment of both validators and students the two weakest indicators are still valid, this indicator is a crucial point which is basically important to note. Indicators of color combination, presentation format, media implementation and media use are indicators that receive high ratings. These results indicate that the performance of this learning media is quite in accordance with existing standards and is easy to use by students. As is well known, most of the students involved are millennials who are at least familiar with the use of digital and animation devices (Bock et al., 2018; Lee, 2016; Smaldino et al., 2012; Zaneldin, Ahmed, \& El-Ariss, 2019).

Judging from the material indicators, learning objectives are the weakest indicator of expert judgment even though they are still in a good level. Meanwhile, the delivery of material and the selection of material above the indicators of learning objectives are still in the appropriate category. These results indicate that it is time for learning objectives and materials related to OHS courses to get the latest updates in accordance with the current conditions of OHS construction. an average score below 90 is another indicator of the need for updating the material. Various understanding of OHS material will have a good impact on construction workers later. The use of standard personal safety equipment such as helmets, safety shoes and wearpacks will have a positive impact on the sustainability of construction workers and their working mentality (Senouci et al., 2015). In construction it is not only related to construction materials but also high-weight objects (Baiburin, 2017) and fire (Q. Wang \& Zhang, 2018). All of them are very relevant and well conveyed in this OHS animation learning video media.

Initial research shows that animated video learning media in OHS courses can be used as variations during the learning process. This is confirmed both through the results of needs analysis and in line with the results of research conducted by Hager, Golonka and Putanowicz (2016) which states that the student's response when given this animated video is able to provide attractiveness and reduce boredom in the learning process as expected. The product of animated video learning media for OHS courses is a 2D animation learning media that is useful for variations in the use of learning media during the learning process, as well as animation video learning media to make it easier to understand learning material (Schneider et al., 2018). The material display in this animated video media is a half-semester material for the OHS course which includes five basic competencies. This animation video learning media consists of 5 videos with a video duration of 5 to 10 minutes. The product of course animation video learning media is packaged using a DVD in which there are instructions for using animated video learning media.

The results and research trials of the development of animation learning media are basically in accordance with student responses when the initial analysis is carried out. Students want a full package of learning media. This means that students need concrete, realistic, interesting and valuable media. Concrete means that the media can present an atmosphere similar to the conditions they will actually face later. Realistic means that students want objects that are similar to the real thing even though they are smaller or with animation in the media. Interesting in the sense that students want media that matches their current interests, such as digital and animation. Value means staying in the corridor of subject learning and not deviating from the material they should have gotten.

The final product of this research is a prototype which still has to be developed. Therefore, an open response and a sharpening of the material is needed prior to larger trials. After more than 6 months of being uploaded on YouTube social media, it has reached 2,000 views, received various responses and based on the traffic data this video has been used in various universities and vocational schools in the field of building construction in various regions. This means that this learning video has received a pretty good response from the audience and is ready to be tested into a larger sample. 


\section{Conclusions and Suggestions}

Based on the results of the research above, it can be concluded that the animated video learning media prototype can be used as a variety of learning media for OHS courses which is very suitable for use in S1 PTB FT UNJ. The use of animated video learning media can increase student enthusiasm and activeness in the learning process. Animated video learning media can be used to reduce boredom during the OHS learning process, especially when learning online. This animated video learning media product can be continued to create even better products. The product of animated video learning media for OHS courses helps lecturers in the learning process.

\section{References}

Akbar, S. (2013). Learning Device Instruments. Rosdakarya Youth.

Arham, U. U., \& Dwiningsih, K. (2016). The Effectiveness of Interactive Multimedia Based on Blended Learning To Improve Student Learning Outcomes. KwangsanJournal, 4(2), 111. https://doi.org/10.31800/jurnalkwangsan.v4i2.89.

Arsyad, A. (2014). Learning Media. Jakarta: Rajawali Press.

Arthur, R., \& Dwi, R. N. (2019). E-Module of Cost Estimating Course in Building Construction Vocational Undergraduate Program Faculty of Engineering Universitas Negeri Jakarta. Jurnal IImu Pendidikan, 25(2), 88-96. http://dx.doi.org/10.17977/um048v25i1 p88-96.

Arthur, R., Luthfiana, Y., \& Musalamah, S. (2019). Analysis of Learning Media Development Needs in Materials Mechanics Courses at Jakarta State University. Journal of $\begin{array}{lll}\text { Educational Building, 5(2), 38-44. } & \end{array}$ https://doi.org/10.24114/ebjptbs.v5i2\%20DES.16084.

Arthur, R., Rouf, F. A., Rahmayanti, H., \& Maulana, A. (2019). Plumbing Work Competence Instrument in the Field of Civil Engineering. Journal of Physics: Conference Series, 1402(2), 1-6. https://doi.org/10.1088/1742-6596/1402/2/022019.

Arthur, R., Sekartaji, G. T., Maulana, A., \& Dewi, L. K. (2019). Video Media Development Presentation on Hydrology Courses at Jakarta State University. Kwangsan Journal of Educationa/Technology , 07(02), 170-183. https://doi.org/10.31800/jtp.kw.v7n2.p170$-183$.

Baena, F., Guarin, A., Mora, J., Sauza, J., \& Retat, S. (2017). Learning Factory: The Path to Industry 4.0. In 7th Conference on Learning Factories (Vol. 9, pp. 73-80). Procedia Manufacturing. https://doi.org/10.1016/j.promfg.2017.04.022.

Baiburin, A. K. (2017). Civil Engineering Quality Assessment in Terms of Construction Safety Index. Procedia Engineering, 206, 800-806. https://doi.org/10.1016/j.proeng.2017.10.554.

Bock, A., Modabber, A., Kniha, K., Lemos, M., Rafai, N., \& Hölzle, F. (2018). Blended learning modules for lectures on oral and maxillofacial surgery. British Journal of Oral and Maxillofacial Surgery, 56(10), 956-961. https://doi.org/10.1016/j.bjoms.2018.10.281.

Dick, W., Carey, L., \& Carey, J. O. (2015). The systematic design of instruction. Pearson.

Endroyo, B., Yuwono, B. E., Mardapi, D., \& Soenarto. (2015). Model of learning/training of Occupational Safety \& Health (OSH) based on industry in the construction industry. In The 5th International Conference of Euro Asia Civil Engineering Forum (Vol. 125, pp. 83-88). Elsevier B.V. https://doi.org/10.1016/j.proeng.2015.11.013.

Furi, U. L., \& Mustaji, N.Y. (2017). Video Media Development Of Digital Photo Composition Subjects for Xi Multimedia Class Students in Vocational High School. Kwangsan Journal, 5(2), 10. https://doi.org/10.31800/jurnalkwangsan.v5i2.43.

Ganah, A., \& John, G. A. (2015). Integrating building information modeling and health and safety for onsite construction. Safety and Health at Work, 6(1), 39-45. https://doi.org/10.1016/j.shaw.2014.10.002. 
Grytnes, R., Grill, M., Pousette, A., Törner, M., \& Nielsen, K. J. (2017). Apprentice or Student? The Structures of Construction Industry Vocational Education and Training in Denmark and Sweden and their Possible Consequences for Safety Learning. Vocations and Learning, 1-23. https://doi.org/10.1007/s12186-017-9180-0.

Grzyl, B., Miszewska-Urbańska, E., \& Apollo, M. (2017). Building Information Modelling as an Opportunity and Risk for Stakeholders Involved in Construction Investment Process. Procedia Engineering, 196(June), 1026-1033. https://doi.org/10.1016/j.proeng.2017.08.045.

Hager, I., Golonka, A., \& Putanowicz, R. (2016). 3D Printing of Buildings and Building Components as the Future of Sustainable Construction? Procedia Engineering, 151, 292-299. https://doi.org/10.1016/j.proeng.2016.07.357.

Hamid, M. A., Aribowo, D., \& Desmira, D. (2017). Development of learning modules of basic electronics-based problem solving in Vocational Secondary School. Journal of Vocational Education, 7(2), 149. https://doi.org/10.21831/jpv.v7i2.12986.

Hokanson, B., Clinton, G., \& Kaminski, K. (2018). Educational Technology and Narrative. cham: Springer International Publishing. https://doi.org/10.1007/978-3-319-69914-1.

Johari, A. (2014). 8 application of video and animation media on vacuuming materials and replenishing student learning outcomes. Journal of Mechanical Engineering Education, $1(1), 8-15$.

Koper, R., \& Tattersall, C. (2010). Learning Design. Springer US. https://doi.org/10.1007/b138966.

Law, K. M. Y., Geng, S., \& Li, T. (2019). Student enrollment, motivation and learning performance in a blended learning environment: The mediating effects of social, teaching, and cognitive presence. Computers \& Education, 136, 1-12. https://doi.org/10.1016/j.compedu.2019.02.021.

Lee, A. Y. L. (2016). Media education in the School 2.0 era: Teaching media literacy through laptop computers and iPads. Global Media and China, 1(4), 435-449. https://doi.org/10.1177/2059436416667129.

Liao, C. W., Chen, C. H., \& Shih, S. J. (2019). The interactivity of video and collaboration for learning achievement, intrinsic motivation, cognitive load, and behavior patterns in a digital game-based learning environment. Computers and Education, 133(January), 43-55. https://doi.org/10.1016/j.compedu.2019.01.013.

Maulana, I. R., Adi, S., \& Hariyanto, E. (2019). Learning Media Based on Autoplay Media Studio For Junior High School. Journal of Education: Theory, Research, AndDevelopment , 4(9), 1177-1184. https://doi.org/10.17977/JPTPP.V4l9.12451.

Miftah, M. (2015). Learning Media: From Conception to Utilization And Its Problems. KwangsanJournal, 3(2), 135. https://doi.org/10.31800/jurnalkwangsan.v3i2.30.

Msonde, S. E., \& Van Aalst, J. (2017). Designing for interaction, thinking and academic achievement in a Tanzanian undergraduate chemistry course. Educational Technology Research and Development, 65(5), 1389-1413. https://doi.org/10.1007/s11423-0179531-4.

Muhson, A. (2010). Development of Information Technology-Based Learning Media. Indonesian Journal of AccountingEducation , $8(2)$, 1-10. https://doi.org/10.21831/JPAI.V8I2.949.

Munir 's. (2014). Multimedia Concepts \& Applications In Education (Vol. 58). Bandung: Alfhabeta. https://doi.org/10.1128/AAC.03728-14.

Pallett, A. C., Nguyen, B. T., Klein, N. M., Phippen, N., Miller, C. R., \& Barnett, J. C. (2018). A randomized controlled trial to determine whether a video presentation improves informed consent for hysterectomy. American Journal of Obstetrics and Gynecology, 219(3), 277.e1-277.e7. https://doi.org/10.1016/j.ajog.2018.06.016. 
Prastiyo, W., Djohar, A., \& Purnawan, P. (2018). Development of Youtube integrated google classroom based e-learning media for the light-weight vehicle engineering vocational high school. Journal of Vocational Education, 83. https://doi.org/10.21831/jpv.v8i1.17356.

Primasari, R., \& Herlanti, Y. (2014). Use of Learning Media in Madrasah Aliah Negeri Se-South Jakarta. UIN Student Journal, 6(1), 67-72. https://doi.org/10.15408/es.v6i1.1101.

Rahman, B. H. (2014). Development of Interactive Learning Media Flash Animation on Competency Standards Installing Simple Building Electric Lighting Installation at SMK Walisongo 2. Journal of Electrical EngineeringEducation, 3(1), 15-21.

Ratnasari, A. (2016). Development of Interactive Learning Media Occupational Safety and Health (OHS) In Electrical Study Program in Vocational High School. Journal of Mecatronika Technical Education Study Program, 6(1), 83-91.

Rayandra, A. (2012). Creatively Develop LearningMedia. Jakarta: Echo press press.

Schneider, S., Beege, M., Nebel, S., \& Rey, G. D. (2018). A meta-analysis of how signaling affects learning with media. Educational Research Review, 23(November 2017), 1-24. https://doi.org/10.1016/j.edurev.2017.11.001.

Senouci, A., Al-Abbadi, I., Eldin, N. (2015). Safety Improvement on Building Construction Sites in Qatar. Procedia Engineering, 123, 504-509. https://doi.org/10.1016/j. proeng.2015.10.102.

Smaldino, S. E., Lowther, D. L., \& Russell, J. D. (2012). Instructional Technology \& Media For Learning (9th ed.). Jakarta: Kencana Prenada Media Group.

Sukir, Soenarto, \& Soeharto. (2017). Developing Conveyor Trainer Kit for Programmable Logic Controllers in. Journal of Vocational Education, 7(3), 329-339.

Susanti, E., Harta, R., Karyana, A., \& Halimah, M. (2018). Effective Learning Video Design In Distance Education: Open University Studies. Journal of Education andCulture , 3(2), 167. https://doi.org/10.24832/jpnk.v3i2.929.

Utami, D. (2011). Animation In Learning. Scientific Magazine oflearning, 7(1), 44-52.

W. Lee, W., \& L. Owens, D. (2004). Multimedia-Based Instructional Design : Computer-Based Training, Web-Based Training, Distance Broadcast Training.

Wang, M. (2018). E-Learning in the Workplace (A Performance-Oriented Approach Beyond Technology). cham: Springer International Publishing. https://doi.org/10.1007/978-3319-64532-2.

Wang, Q., \& Zhang, C. (2018). Fire Safety Analysis of Building Partition Wall Engineering. Procedia Engineering, 211, 747-754. https://doi.org/10.1016/j.proeng.2017.12.071.

Wardoyo Tunggul Cipto, T. (2015). Development of Animated Video-Based Learning Media in Engineering Mechanics Subjects at SMKN 1 Purworejo. E-Journal of Civil Engineering Education AndPlanning, 3(3), 1-7.

William, L., \& Diana, O. (2004). Multimedia Based Instructional Design. Sans Francisco: Pfeiffer.

Zahoor, H., Chan, A. P. C., Utama, W. P., \& Gao, R. (2015). A Research Framework for Investigating the Relationship between Safety Climate and Safety Performance in the Construction of Multi-storey Buildings in Pakistan. Procedia Engineering, 118, 581589. https://doi.org/10.1016/j.proeng.2015.08.488.

Zaneldin, E., Ahmed, W., \& El-Ariss, B. (2019). Video-based e-learning for an undergraduate engineering course. E-Learning and Digital Media, 16(6), 475-496. https://doi.org/10.1177/2042753019870938. 